\title{
Concomitant Immunity to Schistosoma mansoni in Mice
}

\author{
Farelerde Schistosoma mansoni̊ ye karşı konkomitant bağışıklık
}

\author{
Abdel-Moneim Salim, Abdel-Rahman Al-Humiany \\ Department of Medical Microbilogy, Taif University, Turaba, Saudi Arabia
}

\begin{abstract}
Objective: The aim of the present study was to confirm observations on the concomitant immunity to Schistosoma mansoni in mice and assess its effects on the resistance of mice to a challenge infection.

Methods: Cercariae from infected Biomphalaria glabrata were used to infect mice. Twenty mice were infected with a single dose of S. mansoni cercariae. The animals were randomly divided into two groups: experimental group (Group A) and control group (Group B). Group A mice were challenged with the same number of cercariae six weeks after the primary infection. Perfusion of all mice was done 9 weeks after infection in order to obtain worm burdens in relation to their initial cercarial dose. The livers of all mice were obtained for parasitological and pathological assessments.

Results: Our results showed that all the exposed animals became infected with S. mansoni. After a challenge infection, Group A mice had a $54.66 \%$ worm reduction rate, $41.45 \%$ liver egg reduction rate, and $51.76 \%$ granuloma size reduction rate compared to their respective controls. This study shows that mice with persistent adult $S$. mansoni infection are able to mount a very strong regulatory response to a challenge infection. It is concluded that concomitant immunity does occur in mice.

Conclusion: These results describe novel imaging methods that permit visualization of live schistosomes within their living hosts and may help to elucidate mechanisms of infection and also be of value not only for epidemiological investigations, but also in designing government control programs for schistosomiasis. (Turkiye Parazitol Derg 2013; 37: 19-22)
\end{abstract}

Key Words: Schistosoma mansoni, Biomphalaria glabrata, concomitant immunity, mice

Received: 07.04.2012

Accepted: 29.11.2012

\section{ÖZET}

Amaç: Bu çalışmanın amacı farelerde Schistosoma mansoni'ye karşı konkomitant bağışıklık üzerine gözlemleri doğrulamak ve meydan okuyan bir enfeksiyona karşı farelerin direnci üzerindeki etkilerini değerlendirmekti.

Yöntemler: Enfekte Biomphalaria glabrata'dan alınan serkaryalar fareleri enfekte etmek için kullanıldı. Yirmi fare tek doz S. mansoni serkaryası ile enfekte edildi. Hayvanlar rastgele iki gruba ayrıldı: deneysel grup (Grup A) ve kontrol grubu (Grup B). Grup A fareleri birincil enfeksiyondan altı hafta sonra aynı sayıda serkarya ile sınandı. Başlangıç serkarya dozlarıyla ilişkili kurtçuk yükünü elde etmek için tüm farelere enfeksiyondan 9 hafta sonra perfüzyon yapıldı. Bütün farelerin karaciğerleri parazitolojik ve patolojik değerlendirmeler için alındı.

Bulgular: Sonuçlarımız maruz kalan tüm hayvanların S. mansoni ile enfekte olduğunu gösterdi. Karşılaşılan bir enfeksiyondan sonra ilgili kontrolleriyle kıyaslandığında, Grup A farelerde kurtçuk azalma oranı \%54.66, karaciğerdeki yumurta azalma oranı \%41.45, granülom boyutundaki azalma oranı \%51.76 idi. Bu çalışma göstermektedir ki persistant yetişkin S. mansoni enfeksiyonu olan fareler, meydan okuyan bir enfeksiyona çok güçlü bir düzenleyici cevap oluşturabilmektedir. Farelerde konkomitant bağışık oluştuğuna karar verilmiş̧ir.

Sonuç: Bu bulgular canlı şistozomların yaşayan konaklarında görüntülenmesini sağlayan yeni görüntüleme metotlarını tanımlamaktadır ve enfeksiyon mekanizmalarını açıklamaya yardımcı olabilir. Ayrıca bu bulgular, sadece epidemiyolojik araştırmalar için değil, şistozomiyaz için devlet kontrol programları tasarlamak için de önemlidir. (Turkiye Parazitol Derg 2013; 37: 19-22)

Anahtar Sözcükler: Schistosoma mansoni, Biomphalaria glabrata, konkomitant bağışıklık, fare

Geliş Tarihi: 07.04.2012

Kabul Tarihi: 29.11.2012

Address for Correspondence / Yazışma Adresi: Dr. Abdel-Rahman Al-Humiany, Department of Medical Microbilogy, Taif University, Turaba, Saudi Arabia Phone: 00966542871245 E-mail: alhumianny-98@gmail.com doi:10.5152/tpd.2013.05 


\section{INTRODUCTION}

Human schistosomiasis, caused by infection with trematodes belonging to the genus fluke Schistosoma (blood flukes), is one of the most common tropical diseases. Despite the fact that its global distribution has changed significantly, the disease is still a serious public health problem in many countries, affecting between 200-250 million people in developing countries (1, 2). In terms of control strategies for schistosomiasis, enormous efforts have been made to develop effective anti-schistosome vaccines, but none is available at the present time. This may be due to the complexity of the schistosome and its life cycle, in addition to the pathology and morbidity in this chronic disease, which result from the host immune inflammatory response to parasite eggs trapped in the liver and other organs $(3,4)$. A reduction in worm numbers is the "gold standard" for anti-schistosome vaccine development. Concomitant immunity $(\mathrm{Cl})$ has received attention in schistosomiasis and thus we shall motivate this paper with reference to this disease.

Concomitant immunity is characterized by the ability of a host to mount an effective defense against larval stages whilst being unable to clear a persistent burden of adult worms (5). From the parasite perspective, the generation of $\mathrm{Cl}$ may be beneficial as it reduces intraspecic competition within the host. Even if it is beneficial to established parasites, $\mathrm{Cl}$ may not be a parasite adaptation. It may, alternatively, be an incidental effect of an immunological reaction that is shaped by distinct host and parasite adaptations. Smithers et al. (5) transferred adult schistosomes (Schistosoma mansoni) from infected to uninfected monkeys in a series of surgical transplant experiments and later challenged the recipients with large numbers of cercariae. The recipient monkeys were almost totally resistant to the challenge infection, despite having no previous experience of larval schistosome stages, yet were unable to reject the implanted adults. Thus, a curious situation is exposed wherein adult worms are exempt from the immune response that they themselves provoke (6).

Schistosomal antigens are secreted and excreted into the blood from the established adult worms and from the migrating eggs, thereby providing a potent stimulus for the immune system. This response was found against challenge infection in rhesus monkeys, hamsters rabbits and mice $(5,7,8)$. Larval exposure appears to be central to the $\mathrm{Cl}$ found in lymphatic filariasis (9). Thus, there are two distinct sources of antigen that are acting to strengthen immunity against larval challenge and form the mechanistic basis of $\mathrm{Cl}$ : larval-triggered and adult-triggered $\mathrm{Cl}$. From an evolutionary perspective, the latter is more unknowable. Adult-triggered $\mathrm{Cl}$ may be interpreted as similar to vaccination; relatively longliving adult worms vaccinate their host against subsequent challenge infection. Autopsy data on Schistosoma haematobium infection in Egypt are suggestive of an even stronger impact of parasite density on individual fecundity. Here the mean egg output of a heavily infected host appeared to be lower than that of a host with fewer worms, and this was assumed to result from acquired immune responses to both past and current infection (10). These studies thereby provided a strong immunological basis for $\mathrm{Cl}$. However, a few authors have suggested that the mechanism of resistance may be related to the hepatic pathology caused by the primary infection $(11,12)$. The vascular pathology might enable the challenge schistosomula to escape from the hepatic portal system, thus preventing normal parasite sequestration and maturation in the liver.

\section{Objectives of the Present Study}

The overall objective of this study was to test the effect of previous infection with $S$. mansoni on the resistance of mice to a challenge infection $(\mathrm{Cl})$ by comparing the following parameters with those obtained from age-matched control mice:

1. Parasitological parameters, such as the numbers of the recovered adult worms and the numbers of eggs retained in the liver in term of egg per gram (EPG) liver tissue.

2. Pathological parameters such as granuloma size.

The results of this study are expected to contribute towards the development of effective control programs.

\section{METHODS}

\section{Animals}

BALB/c male, naïve mice aged six to seven weeks were used in all experiments. The animals were divided randomly into 3 groups of 10 animals each, housed in polypropylene cages (445x280x125mm; Labotec, Johannesburg, South Africa) on wood shavings, 10 mice per cage. Each cage is approximately $15 \mathrm{M} 2$ in area and is maintained under positive pressure, having an average temperature of $25 \pm 2^{\circ} \mathrm{C}$ with $12 \mathrm{~h} / 12 \mathrm{~h}$ light/dark cycle, humidity of 50-600/0 and receiving 10-13 air changes per hour. Tap water and standard rodent food pellets (Epol, Pietermaritzburg, South Africa) were provided "ad libitum".

\section{Parasites and Snails Materials}

The cercariae were obtained from laboratory raised and infected Biomphalaria glabrata. Cercaria shedding was induced by subjecting infected, water-immersed snails to light for 1.5 hours. The cercariae were concentrated by cooling and low speed centrifugation. After collecting from the infected snails, the cercariae were placed on coverslips and the number of cercariae used for each animal was accurately counted under a dissecting microscope.

\section{Infection of Mice}

Each animal was exposed to percutaneous infection by approximately $100 \pm 2$ S. mansoni cercariae using the paddling method (13). Briefly, animals were placed individually into $600 \mathrm{~mL}$ plastic beakers containing $80 \mathrm{~mL}$ of dechlorinated tap water and the appropriate number of cercariae. After $45 \mathrm{~min}$, they were returned to their cages. All animals were infected on the same day within a period of 5 hours. The time between the primary and the challenge infection was six weeks, except where stated otherwise.

\section{Experimental Design}

After cercarial exposure, the animals were randomly divided into two groups, each one with 10 mice, as follows:

(a) Group A (Concomitant mice, previously-infected): was designed to evaluate the effect of the concomitant immunity to challenge infection. Mice in this group were challenged with the same number of cercariae six weeks after primary infection. 
(b) Group B: Infected control-mice: these were mice with primary infection. They were infected and given distilled water, daily, from the $1^{\text {st }}$ day of infection till the end of the $9^{\text {th }}$ week post-infection.

\section{Adult Worm Recovery}

Nine weeks after cercarial exposure, all mice were sacrificed by cervical dislocation, and worms were recovered from the portal system and mesenteric veins by the vascular perfusion technique. The perfused saline plus blood drained through the portal vein was recovered in a beaker, and left to sediment. The supernatant was discharged and the sediment washed out twice with saline. After washings the recovered worms were counted under a magnifying lens.

The percentage of reduction for each group and each experiment was calculated according to the following formula:

$\%$ reduction $=$ (mean of worms in control group - mean of worms in control treated) $\times 100 /$ (mean of worms in control group).

\section{Liver Egg Counts (EPG)}

At the time of perfusion, whole livers of experimental and control mice were weighed and a known portion $(0.5 \mathrm{~g})$ was removed to a screw cap glass tube and frozen until digestion. The frozen sample of the liver was minced. For digestion $5 \mathrm{~mL}$ of $5 \% \mathrm{KOH}$ (Potassium hydroxide) was added to each tube and incubated at $37^{\circ} \mathrm{C}$ until the tissue was completely digested (10-12 hours). Egg counts of three $1 \mathrm{~mL}$ portions of the suspension were determined by microscopic examination at $40 \mathrm{X}$. Total egg counts were expressed for each group of mice as the mean number of eggs /gram of mouse liver (the EPG liver).

\section{Liver Granuloma Measurement}

Granuloma diameters were measured in histological sections. After portal perfusion, part of the liver tissue was immediately fixed in $10 \%$ buffered formalin solution and processed in paraffin blocks. Paraffin sections were routinely stained with hematoxylin-eosin (HE) for microscopic examination. In each histological section, 10 granulomas with visible central eggs were randomly selected; their diameters were measured at $10 \mathrm{X}$ magnification using a calibrated ocular micrometer. Two perpendicular maximal diameters were measured, obtaining the mean diameter for each granuloma and then calculating the mean granuloma diameter for each mouse in a group and the sizes in a group were averaged for statistical comparison.

\section{Statistical Analysis 2.8.}

Data were presented as mean \pm SD. Group means and standard deviations for all groups were calculated and compared. Statistical significance was assessed by Student's t-test. Values of $\mathrm{p}<0.05$ were taken to be significant.

\section{RESULTS}

In order to measure the degree of protection conferred by concomitant immunity, Group A mice were challenged with S. mansoni normal cercariae. Worm burden, egg count in the liver, and hepatic granuloma size were determined for each group. The results are shown in Tables 1-3.

\section{Worm Recovery}

Infections were obtained in all mice. Immature worms were recovered from mice in both groups. These immature worms
Table 1. Comparison of worm numbers recovered from different groups

\begin{tabular}{|l|c|c|c|c|}
\hline Group & $\begin{array}{c}\text { Infection } \\
\text { status }\end{array}$ & $\begin{array}{c}\text { Worm } \\
\text { burden }\end{array}$ & $\begin{array}{c}\% \\
\text { Protection }\end{array}$ & $\begin{array}{c}\mathbf{p} \\
\text { value }\end{array}$ \\
\hline A & Challenge infection & $27.50 \pm 5.00$ & 54.66 & $<0.001$ \\
\hline B & Primary infection & $60.66 \pm 5.85$ & 29.11 & \\
\hline \multicolumn{4}{|l}{ The number of cercariae used for primary / challenge infections was 100} \\
\hline
\end{tabular}

Table 2. Mean number of tissue egg counts and the percentage reduction in challenge egg deposition in the liver

\begin{tabular}{|l|c|c|c|c|}
\hline Group & $\begin{array}{c}\text { Infection } \\
\text { status }\end{array}$ & $\begin{array}{c}\text { Mean } \\
\text { EPG }\end{array}$ & Reduction & $\begin{array}{c}\text { p } \\
\text { value }\end{array}$ \\
\hline A & Challenge infection & $468.75 \pm 42.69$ & 41.45 & $<0.001$ \\
\hline B & Primary infection & $800.66 \pm 19.00$ & & \\
\hline
\end{tabular}

Table 3. Granuloma sizes in different groups of mice 9 weeks after a single dose of 100 cercariae/mice

\begin{tabular}{|l|c|c|c|c|}
\hline Group & $\begin{array}{c}\text { Infection } \\
\text { status }\end{array}$ & $\begin{array}{c}\text { Granuloma } \\
\text { size }(\boldsymbol{\mu m})\end{array}$ & Reduction & $\begin{array}{c}\mathbf{p} \\
\text { value }\end{array}$ \\
\hline $\mathrm{A}$ & Challenge infection & $49.30 \pm 6.68$ & 51.76 & $<0.01$ \\
\hline $\mathrm{B}$ & Primary infection & $102.2 \pm 17.14$ & & \\
\hline
\end{tabular}

were included in figures for total worm burdens. Statistical analysis of the obtained data, presented in Table 1, showed that the application of concomitant immunity evoked a highly significant reduction $(t=8.1012 ; p<0.001)$ in the mean worm count nine weeks after cercarial exposure as compared to the primary infected mice. This reduction was $54.66 \%$.

\section{Liver Egg Counts}

The mean number of eggs deposited in the liver in the primary control mice was found to be $800.66 \pm 19.00$ EPG. It was $486.75 \pm 42.69$ in Group A, showing a highly significant decrease of $41.45 \%$ in the total liver eggs $(t=12.34, p<0.001)$, Table 2 .

\section{Granuloma Size}

In spite of the presence of lesions throughout the liver of all mice, however, significant differences in the tissue response to schistosome eggs were noted. The mean granuloma sizes after the challenge infection were $49.30 \pm 6.68 \mu \mathrm{m}$ in group $A$, and 102.2 \pm 17.14 $\mu \mathrm{m}$ in the control group (group B). Thus, after a challenge infection, mice previously infected with S. mansoni developed lesions that were, on average, $51.76 \%$ smaller than those formed in mice with primary infection $(t=5.765, p<0.01)$, Table 3 .

\section{DISCUSSION}

Infection with Schistosoma spp. in the rat has been extensively studied, and offers several biological and immunological features which render this host an ideal model for the study of this parasite. This study confirms the possibility of the concomitant immunity $(\mathrm{Cl})$ as one of these features. Previous experimental studies on $\mathrm{Cl}$ indicate that this feature is an immunological process and is called 'self-cure phenomenon' $(14,15)$. It was observed between the $4^{\text {th }}$ and the $11^{\text {th }}$ week, as measured by the liver perfusion technique, or by the lung recovery method (16-19). The exact mechanism of $\mathrm{Cl}$ as a phase of acquired immunity is still unclear, 
but many in vitro studies suggested the involvement of antibodies and non-sensitized cells in this process (20-22).

This study indicates that we have successfully established a new concomitant immunity model in mice with the following characteristics:

Resistance in previously infected mice to a challenge infection led to a $54.66 \%$ worm reduction rate, $41.45 \%$ liver egg reduction rate, and $51.76 \%$ granuloma size reduction rate, as compared to naive mice facing a similar challenge infection. Therefore, mice with previous S. mansoni infection are able to mount a very strong regulatory response to a challenge infection, which could be termed concomitant immunity.

The development of $\mathrm{Cl}$ found in mice could be due to the following reasons:

First, the inhibition of egg production eliminates the excretion of soluble egg antigens (SEA) and, hence, the production of blocking antibodies as shown previously in NM mice, which may explain the enhancement of $\mathrm{Cl}(23)$.

Second, comparing with the irradiated vaccine model, established by McLaren et al. (24), the protection against reinfection due to concomitant immunity is dependent on the living adult worms in NM mice. This is supported by Brown et al. (25), who concluded that adult worms might promote anti- larval immunity via the release of antigens, thus creating a barrier against continuous infection and limiting burden size within the host. This adult-triggered $\mathrm{Cl}$ may be interpreted as similar to vaccination; relatively long-living adult worms "vaccinate" their host against subsequent challenge infection.

From the above discussion, it seems that our results strongly support the hypothesis first proposed by Smithers et al. (5) in 1969 that the resistance of the definitive host to schistosome reinfection is related to concomitant immunity induced by adult worms in vivo, which does not affect the established adult worms but does affect reinfection with the parasite in the larval stage.

\section{CONCLUSION}

These results may have important implications not only for epidemiological investigations, but also in designing government control programs for schistosomiasis including anti-schistosome vaccine.

\section{Conflict of Interest}

No conflict of interest was declared by the authors.

\section{REFERENCES}

1. Copeland CS, Brindley PJ, Heyers O. Boudicca, a retrovirus-like long terminal repeat retrotransposon from the genome of the human blood fluke Schistosoma mansoni. J Virol 2003; 77: 6153-66. [CrossRef]

2. WHO. Prevention and control of schistosomiasis and Soiltransmitted helminthiasis. The Joint WHO Expert Committees. Genava: 2002. Technical Report Series 912.

3. Bergquist NR. Schistosomiasis: from risk assessment to control. Trends Parasitol 2002; 18: 309-14. [CrossRef]
4. Capron A, Riveau GJ, Bartley, PB, McManus DP. Prospects for a schistosome vaccine. Curr Drug Targets Immune Endocr Metabol Disord 2002; 2: 281-90. [CrossRef]

5. Smithers SR, Terry RJ. Immunity in schistosomiasis. Ann N Y Acad Sci 1969; 160: 826-40. [CrossRef]

6. Smithers SR, Terry RJ. The infection of laboratory hosts with cercariae of Schistosoma mansoni and the recovery of the adult worms. Parasitology 1965; 55: 695-700.

7. Tendler M, Pinto RM, Oliveira Lima A, Gebara G, Katz N. Schistosoma mansoni: vaccination with adult worm antigens. Int J Parasitol 1986; 16: 347-52. [CrossRef]

8. Cutts $\mathrm{L}$, Wilson RA. The protein antigens secreted in vivo by adult male Schistosoma mansoni. Parasitology 1997; 114: 245-55. [CrossRef]

9. Maizels RM, Lawrence RA. Immunological tolerance: The key feature in human filariasis? Parasitol Today 1991; 7: 271-6. [CrossRef]

10. Cheever AW, Kamel IA, Elwi AM, Mosimann JE, Danner R, Sippel JE. Schistosoma mansoni and S. haematobium infections in Egypt. III. Extrahepatic pathology. Am J Trop Med Hyg 1978; 27: 55-75.

11. Wilson RA, Coulson PS, McHugh SM. A significant part of the 'concomitant immunity' of mice to Schistosoma mansoni is the consequence of a leaky hepatic portal system, not immune killing. Parasite Immunol 1983; 5: 595-601. [CrossRef]

12. McHugh SM, Coulson PS, Wilson RA. Pathologically induced alterations in the dimensions of the hepatic portal vasculature of mice infected with Schistosoma mansoni. Parasitology 1987; 94: 69-80. [CrossRef]

13. Frandsen F. Cultivation of schistosomes for chemotherapeutic studies. Acta Pharmacol Toxicolo 1981; 49: 118-22. [CrossRef]

14. Phillips SM, Reid WA, Bruce Jl, Hedlund K, Colvin RC, Campbell R, et al. The cellular and humoral immune response to $S$. mansoni infections in inbred rats. I. Mechanisms during initial exposure. Cell Immunol 1975; 19: 99-116. [CrossRef]

15. Cioli D, Dennert G. The course of Schistosoma mansoni infection in thymectomized rats. J Immunol 1976; 117: 59-65.

16. Smithers SR, Terry RJ. Acquired resistance to experimental infections of S. mansoni in the albino rat. Parasit 1965; 55: 711-9.

17. Knopf PM, Nutman TB, Reasoner JA. S. mansoni: resistance to reinfection in the rat. Exp Parasit 1977; 41: 74-81. [CrossRef]

18. Phillips SM, Reid WA, Sadun EH. The cellular and humoral immune response to $S$. mansoni infection in inbred rats. II. Mechanisms during reexposure. Cell Immunol 1977; 28: 75-83. [CrossRef]

19. Perez HA, Smithers SR. Schistosoma mansoni in the rat: the adherence of macrophages to schistosomula in vitro after sensitization with immune serum. Int Journal Parasit 1977; 7: 315-8. [CrossRef]

20. Dean DA, Wistar R, MuRuell KD. Combined in vitro effects of rat antibody and neutrophilic leukocytes on schistosomula of $S$. mansoni. Am J Trop Med Hyg 1974; 23: 420-7.

21. Perez HA, Clegg JA, Smithers SR. Acquired immunity to Schistosoma mansoni in the rat: measurement of immunity by the lung recovery technique. Parasit 1974; 69: 34915-20. [CrossRef]

22. Capron A, Dessaint JP, Capron M, Bazin H. Specific IgE antibodies in immune adherence of normal macrophages to Schistosoma mansoni schistosomules. Nature (Lond.) 1975; 253: 47-52. [CrossRef]

23. Yi XY, Simpson AJ, de Rossi $R$ and Smithers SR. The presence of antibody in mice chronically infected with Schistosoma mansoni which blocks in vitro killing of schistosomula. J Immunol 1986; 137: 3955-8.

24. McLaren DJ, Rogers MV. Schistosoma mansoni: liver phase challenge attrition is a stage-dependent phenomenon in guineapigs vaccinated with highly irradiated cercariae. Parasite Immunol 1986; 8: 307-18. [CrossRef]

25. Brown SP, Grenfell BT. An unlikely partnership: parasites, concomitant immunity and host defense. Proc R Soc Lond B 2001; 268: 2543-9. [CrossRef] 